\title{
Effects of low-impact logging on understory birds in the Brazilian
}

\section{Amazon}

\author{
José CR Soares ${ }^{(1-2)}$, \\ Adriene O Amaral ${ }^{(1)}$, \\ Roberta S De Moura ${ }^{(3)}$, \\ Ricardo AS Cerboncini ${ }^{(2)}$, \\ Louri Klemann Junior ${ }^{(2-3)}$
}

\begin{abstract}
Tropical forests have a great potential for the exploitation of natural resources. Among the economic activities that depend on forest resources, timber production is the most important one. Nevertheless, these activities may negatively affect wildlife, the availability of natural resources, and ecosystem process. Here we analysed the effects of low-impact logging on understory bird species richness, number of individuals captured, species composition, and assemblage structure in central Brazilian Amazon. We compared logged and unlogged areas over a period of three years (from August 2014 to May 2017). We captured a total of 180 birds and 42 species (20 families) in the logged area and 226 birds and 49 species (20 families) in the unlogged area. Bird assemblage structure in the logged area changed more intensely over the three years of study and became more similar to the assemblage found in the unlogged area. The degree of similarity (Jaccard's index) in species composition between logged and unlogged areas increased from $18 \%$ in the third year to $39 \%$ in the fifth year after logging. The results suggest that the minor effects of low-impact logging were reduced a few years after the disturbance, probably due to ecological succession. The proximity of logged and unlogged areas and the reduced impact in the study site may facilitate the recovery of the bird assemblage after the disturbance.
\end{abstract}

Keywords: Biodiversity, Conservation, Environmental Disturbance, Forest Resources, Sustainable Development

biodiversity loss by the destruction of these forests (Thinh et al. 2012, Hansen et al. 2013). Agricultural expansion, fires, logging, and unplanned exploitation of forest resources are among the major threats to tropical forests (Edwards et al. 2014, Jamhuri et al. 2018). In this sense, sustainable forest management (SFM) is proposed as a way of using forest resources without compromising their availability for future generations (MacDicken et al. 2015).

Low-impact logging is one of the mostly approached techniques of SFM and consists in planning the construction of roads, drag lines, stockyards, and trails, as well as managing the direction of treefall (Putz et al. 2008, Jonkers \& Hendrison 2011). This planned and carefully controlled system of timber harvesting aims to minimize the negative impacts of logging by allowing the recovery of forests after logging (Putz et al. 2008). However, the sustainability of this type of activity may be questioned as the productivity may intensely drop after the first cutting cycle to less than $70 \%$ of the initial yield (Dauber et al. 2005, Sist \& Ferreira 2007). The association with other silvicultural techniques, such as control of lianas and non-commercial competing species, can contribute to keep the forests healthy and productive after the first logging (Putz et al. 2008). Nevertheless, the consequences of low-impact logging in tropical forests may still be devastating (Shearman et al. 2012).
After logging, changes in the forest struc ture consequently affect animal species. The intensity of the impacts on wildlife is related to the extension of the logged area, the number and volume of trees removed from the natural ecosystems, and the elapsed time after logging (Henriques et al. 2008). The main effects are the reduction in the number of species and individuals, and changes in species composition (Chaves et al. 2017, Jamhuri et al. 2018, Lindenmayer et al. 2019). These effects can also alter the structure of animal assemblages (Costantini et al. 2016, Jati et al. 2018).

Bird species play an important role in ecological processes, such as in pollination, seed dispersion, and seed predation (Whelan et al. 2008, Michel et al. 2020). The effects of low-impact logging on birds are often less intense than those of other types of disturbances (Barlow et al. 2002). Nevertheless, this type of activity may affect bird species, especially cavity-nesters and understory birds (Aleixo 1999, Henriques et al. 2008, Costantini et al. 2016, Ibarra et al. 2017). In tropical forests, low-impact logging may affect bird species composition (Wunderle et al. 2006, Cleary et al. 2007), population density and habitat use (Chaves et al. 2017), inter-species interactions in mixed flocks (Borah et al. 2018), and phylogenetic diversity (Mestre et al. 2020). These negative impacts call into question the adequacy of SFM practices for eco- 
nomic and social development in the Tropics.

Logging is one of the main threats to biodiversity and also one of the most important economic activities in tropical forest (MacDicken et al. 2015). Thus, understanding the impacts of low-impact logging on biodiversity allows an evaluation of this type of activity as an alternative for sustainable development. To detect the effects of SFM on metrics of biodiversity, we captured and identified birds in logged and unlogged forests in Central Brazilian Amazon. We searched for evidence of the recovery of the bird assemblage in the logged area after the disturbance due to ecological succession. For that purpose, we tested whether species richness, number of individuals captured, bird diversity, species composition, and assemblage structure changed over the three years of study similarly in low-impact logged and unlogged areas.

\section{Material and methods}

\section{Study site}

We studied birds in two areas owned by Precious Woods Amazon (PWA) Ltd. in the municipality of Silves $\left(02^{\circ} 43^{\prime} 12.3^{\prime \prime} \mathrm{S}, 58^{\circ} 31^{\prime}\right.$ $44.73^{\prime \prime} \mathrm{W}$ ), state of Amazonas, Brazil. Vegetation is typical of low-land rainforests (Floresta Pluvial Tropical de Terra Firme) with large, emergent trees reaching 35 to $52 \mathrm{~m}$ above the ground and with the presence of woody lianas (Oliveira et al. 2008). The forest management system in the study site is polycyclic and allows the regeneration of the native forest after exploitation (i.e., CELOS Management System - De Graaf \& Poels 1990). Low-impact logging techniques include: the selection and mapping of all trees to be harvested (only a subset of all trees with diameter at breast height $\geq$ $50 \mathrm{~cm}$ ); planning the construction of roads, stockyards, and dragging trails; and directing tree fall to minimize environmental impact (Wellhöfer 2002).

We had access to the results of the inventory of all trees with diameter at breast height $\geq 40 \mathrm{~cm}$ performed by PWA in both sampled areas before exploitation. One of the areas (hereafter, logged area - 4535 ha) was logged during 2012 with intensity of $20.36 \mathrm{~m}^{3} \mathrm{ha}^{-1}$, approximately $30 \%$ of forest production capacity. The second area (hereafter, unlogged area - 7164 ha) was not used for low-impact logging activities before or during the study. Similarity between the logged area $(87,318$ individuals, 80 species, Shannon Diversity Index H: 3.6 ) and the unlogged area (95,177 individuals, 66 species, $\mathrm{H}: 3.51$ ) in tree species composition (Jaccard's index) was $78 \%$ and in tree assemblage structure (1 - Bray-Curtis dissimilarity) was $73 \%$. Both areas sum up 9751.78 ha and are part of a mosaic of areas destined to low-impact logging exploited since 1995, in a total of more than 200,000 ha. The distance between sampled areas is $3 \mathrm{~km}$ (Fig. 1).

\section{Data collection}

As the interval between the end of the disturbance and the beginning of field sampling may affect the results (Bicknell \& Peres 2010), bird sampling in both areas started two years after exploitation to avoid detecting effects not related to ecological succession. We sampled birds between August 2014 and May 2017, in March, May, September, and November, totalling four samples per year in each area.

Each sample was conducted during two consecutive days by using twelve mist-nets

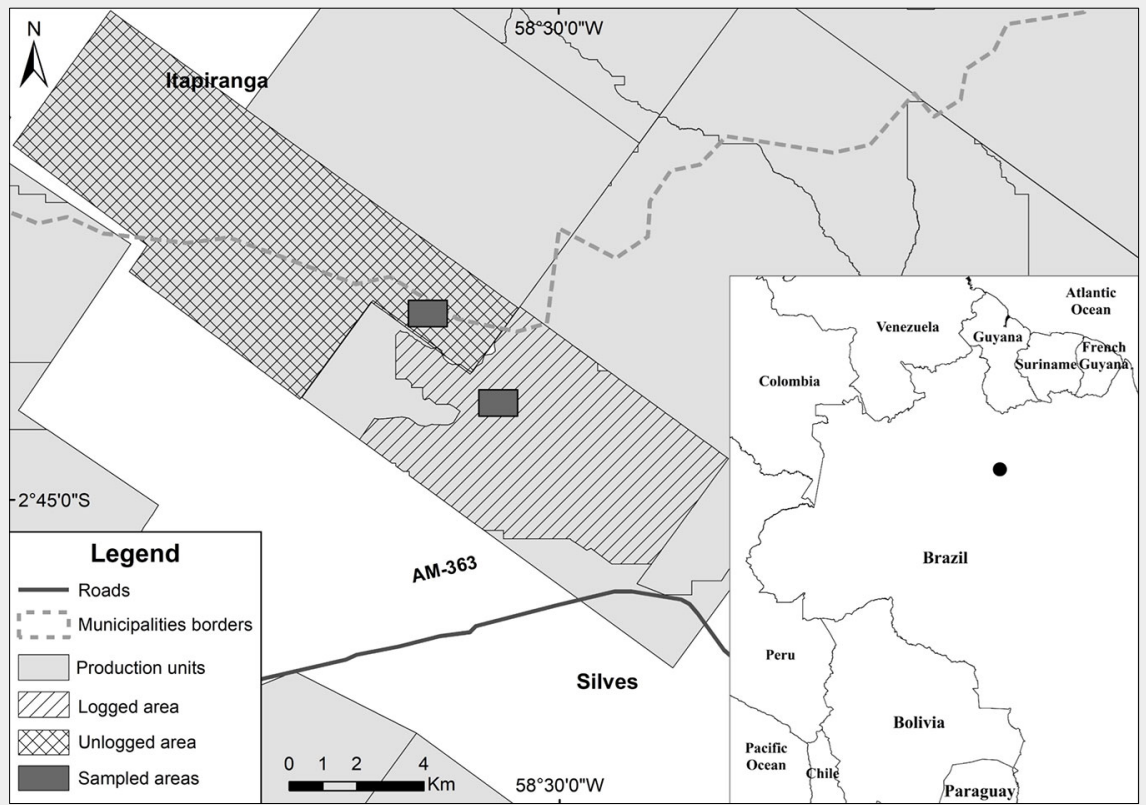

Fig. 1 - Location of the logged and the unlogged areas in the study site in Central Brazilian Amazon.
(3 m height, $12 \mathrm{~m}$ length, mesh size $20 \times 20$ $\mathrm{mm}$ ) concomitantly along $150 \mathrm{~m}$ long transects. Sampling started at sunrise and stopped at sunset (11 hours per day), totalling 264 mist-nets per hours per sample (12 mist-nets $\times 11$ hours per day $\times 2$ days) and 6336 mist-nets per hours in the study (264 mist-nets per hours per sample $\times 12$ samples $\times 2$ areas). Captured birds were identified at the species level and banded with metal rings from the Brazilian Bird Banding Agency (Centro Nacional de Pesquisa para a Conservação das Aves Silvestres CEMAVE).

\section{Statistical analysis}

As our objective was to determine shortterm temporal changes in bird assemblage, we calculated biodiversity metrics for each sample. Species richness was determined as the number of species and bird diversity as the Shannon-Wiener index ( $\left.\mathrm{H}^{\prime}\right)$. To determine assemblage structure, we performed a non-metric multidimensional scaling (NMDS) based on the Bray-Curtis dissimilarity and calculated from a Hellinger transformed matrix with the number of individuals captured for each species. We started reducing the variability into two NMDS components and increased the number of components until a solution with stress $<20 \%$ was reached. As different groups of species may respond differently to the environmental fluctuations, we considered each NMDS component as a representative of a part of the bird assemblage structure.

We used Analysis of Covariance (ANCOVA) to test the effects of the time elapsed after logging on bird biodiversity metrics. We built covariance models with the number of days after logging for each sample and the identity of the area (logged vs. unlogged) as explanatory variables, and one of the biodiversity metrics (species richness, number of individuals captured, bird diversity, and bird assemblage structure) as the response variable. For bird assemblage structure, we tested each of the NMDS components separately. Significant results were based on F-tests with $\mathrm{p}<0.05$.

We also evaluated changes in bird species composition by calculating Jaccard's dissimilarity index between the logged and the unlogged areas in different years of sampling. Bird assemblages of the four samples per year were gathered for this analysis. Results are reported as percentage of similarity.

\section{Results}

During the three years of study, we captured 406 birds, 63 species, and 24 families (Tab. 1, Tab. S1 in Supplementary material). From all species, $35(56 \%)$ were detected in only one of the areas, 14 were only captured in the logged area, and 21 species only in the unlogged area. In the logged area, we captured 180 individuals and 42 species (20 families), while in the unlogged area we captured 226 individuals and 49 
Tab. 1 - Spearman correlation between the number of individuals captured for each species and NMDS components of bird assem blage structure in logged and unlogged areas in central Brazilian Amazon. (*): indicate that the absolute value of correlation (rho) is greater than or equal to 0.4 .

\begin{tabular}{|c|c|c|c|c|c|c|c|}
\hline Species & NMDS1 & NMDS2 & NMDS3 & Species & NMDS1 & NMDS2 & NMDS3 \\
\hline Attila spadiceus & -0.26 & -0.21 & 0.23 & Mionectes macconnelli & -0.12 & $0.72^{*}$ & 0.27 \\
\hline Automolus cervicalis & 0.15 & 0.11 & 0.28 & Mionectes oleagineus & -0.33 & -0.32 & -0.13 \\
\hline Automolus ochrolaemus & $0.60^{*}$ & $0.42^{*}$ & 0.2 & Momotus momota & 0.14 & 0.2 & 0.35 \\
\hline Campylorhamphus procurvoides & -0.32 & -0.23 & -0.14 & Myiobius barbatus & 0.04 & -0.39 & -0.02 \\
\hline Ceratopipra erythrocephala & $-0.71^{*}$ & 0.18 & 0.07 & Myrmoderus ferrugineus & -0.17 & 0.32 & -0.23 \\
\hline Certhiasomus stictolaemus & -0.15 & -0.1 & $0.46^{*}$ & Myrmornis torquata & $0.42^{*}$ & -0.3 & -0.06 \\
\hline Clibanornis obscurus & 0.08 & -0.35 & -0.11 & Myrmotherula axillaris & $0.44^{*}$ & -0.2 & 0.35 \\
\hline Corapipo gutturalis & -0.07 & 0.02 & 0.2 & Myrmotherula longipennis & $0.53^{*}$ & 0.21 & -0.3 \\
\hline Corythopis torquatus & 0.23 & 0.29 & 0.08 & Percnostola subcristata & $-0.43^{*}$ & -0.38 & -0.09 \\
\hline Cyanoloxia rothschildii & -0.03 & -0.32 & -0.04 & Phaethornis bourcieri & 0.35 & -0.08 & 0.23 \\
\hline Cymbilaimus lineatus & 0.26 & -0.2 & 0.26 & Phaethornis superciliosus & -0.23 & -0.19 & $-0.42^{*}$ \\
\hline Deconychura longicauda & 0.1 & 0.02 & 0.02 & Pheugopedius coraya & 0.08 & -0.35 & -0.11 \\
\hline Dendrocincla fuliginosa & -0.13 & 0.21 & 0.18 & Philydor erythrocercum & $0.54^{*}$ & -0.08 & 0.25 \\
\hline Dendrocincla merula & 0.26 & 0.35 & 0.3 & Phoenicircus carnifex & -0.02 & 0.26 & 0.03 \\
\hline Dendrocolaptes certhia & 0.1 & -0.34 & 0.07 & Pithys albifrons & $0.59^{*}$ & 0.11 & 0.3 \\
\hline Dixiphia pipra & 0.3 & -0.17 & $0.56^{*}$ & Platyrinchus saturatus & 0.29 & 0.14 & -0.08 \\
\hline Epinecrophylla gutturalis & $0.44^{*}$ & 0.17 & -0.3 & Ramphastos vitellinus & 0.35 & -0.08 & 0.23 \\
\hline Formicarius colma & 0.09 & 0.09 & 0.19 & Schiffornis turdina & -0.35 & -0.02 & -0.2 \\
\hline Frederickena viridis & -0.1 & -0.12 & 0.38 & Sclerurus macconnelli & 0.29 & 0.14 & -0.08 \\
\hline Galbula albirostris & 0.33 & -0.32 & 0.16 & Selenidera piperivora & $-0.46^{*}$ & 0.15 & -0.07 \\
\hline Geotrygon montana & $-0.47^{*}$ & 0.14 & -0.21 & Sittasomus griseicapillus & 0.08 & -0.35 & -0.11 \\
\hline Glyphorynchus spirurus & 0.01 & -0.01 & -0.26 & Tangara varia & 0.17 & -0.17 & -0.26 \\
\hline Gymnopithys rufigula & 0 & 0.06 & $0.62^{*}$ & Terenotriccus erythrurus & 0.14 & 0.2 & 0.35 \\
\hline Hemitriccus minor & 0.32 & 0.11 & -0.35 & Thalurania furcata & 0.2 & -0.26 & -0.05 \\
\hline Hylexetastes perrotii & 0.31 & 0.02 & 0.11 & Thamnomanes ardesiacus & $0.49^{*}$ & $0.40^{*}$ & 0.17 \\
\hline Hypocnemis cantator & -0.15 & -0.02 & -0.14 & Thamnomanes caesius & 0.32 & 0.22 & -0.16 \\
\hline Lanio fulvus & -0.08 & -0.1 & -0.1 & Thamnophilus murinus & -0.23 & -0.09 & -0.11 \\
\hline Lanio surinamus & 0.33 & 0.19 & -0.06 & Trogon rufus & -0.32 & -0.23 & -0.14 \\
\hline Laniocera hypopyrra & -0.02 & -0.05 & -0.02 & Turdus albicollis & $0.79^{*}$ & 0.08 & -0.31 \\
\hline Lepidocolaptes albolineatus & 0.32 & 0.11 & -0.35 & Xenops minutus & 0.26 & -0.2 & 0.26 \\
\hline Lipaugus vociferans & 0.14 & 0.2 & 0.35 & Xiphorhynchus pardalotus & 0.13 & $-0.54^{*}$ & -0.18 \\
\hline Micrastur ruficollis & 0.14 & 0.2 & 0.35 & & - & - & - \\
\hline
\end{tabular}

species (20 families).

Low-impact logging did not affect species richness $\left(\mathrm{F}_{[3,20]}=0.54, \mathrm{p}=0.663\right)$, number of individuals captured $\left(\mathrm{F}_{[3,20]}=0.96, \mathrm{p}=\right.$
$0.429)$, and bird diversity $\left(F_{[3,20]}=0.51, p=\right.$ scores $)$. ANCOVA indicated that the assem$0.679)$. Variation in bird assemblage struc- blage structure changed over time differture was reduced into three NMDS compo- ently in logged and unlogged areas for two nents (stress $=0.15-$ see Tab. 1 for species NMDS components (NMDS1: $F_{[3,20]}=11.31, p$
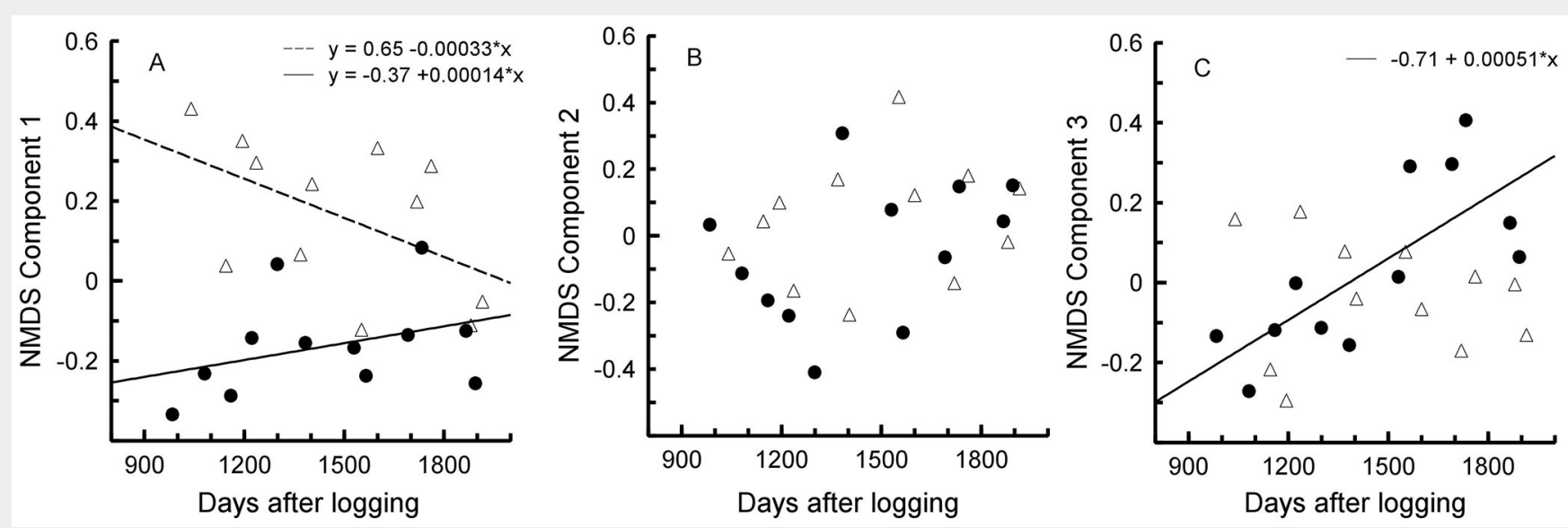

Fig. 2 - Changes in bird assemblage composition as determined by Non-metric Multidimensional Scaling (NMDS) from three to five years after logging in logged (filled circles, solid line) and unlogged (open triangles, hatched line) areas. 
$=0.0001 ; \operatorname{NMDS} 2: \mathrm{F}_{[3,20]}=1.18, \mathrm{p}=0.342$; NMDS3: $\left.F_{[3,20]}=4.53, p=0.014\right)$. The first component (NMDS1) represents a group of species in the assemblage structure that became more similar between the logged and the unlogged areas over time (Fig. 2A). The second component represents a group of species that were not affected by low impact logging (Fig. 2B). The third component (NMDS3) represents a group of species that changed over time in the logged area only (Fig. 2 C).

Jaccard's similarity index between the logged and unlogged areas increased over time, from $18 \%$ in the third year, to $25 \%$ in the fourth year, and to $39 \%$ in the fifth year after logging.

\section{Discussion}

Our results show an increase in similarity in bird assemblage structure between the logged and the unlogged areas over a short period of time. However, responses of the bird assemblage to the effects of low-impact logging were complex, and some species contributed to an increase in dissimilarity between the areas (Fig. 2C). The logged area was more intensely affected by changes in the bird assemblage during the study, probably due to ecological succession after disturbance (MontejoKovacevich et al. 2018). Changes in forest structure may result from the opening of clearings, stockyards, roads, and drag lines (Gatti et al. 2015).

Species richness, number of individuals captured, and bird diversity were similar between the logged and unlogged areas, although observed total values were slightly lower in logged forests (14\% less rich and $20 \%$ less abundant - see Tab. S1 in Supplementary material). After logging, bird species richness and abundance may decrease (Guilherme \& Cintra 2001, Henriques et al. 2008). Ecological succession increases the complexity of forest structure, which in turn may lead to a greater diversity of birds (Batisteli et al. 2018). The slight observed reduction in bird richness and number of individuals captured may be a consequence of low-impact changes in microclimatic conditions (e.g., temperature, humidity, luminosity) and in vegetation structure that happened only in the logged area.

Changes in species composition due to low-impact logging may be a result of the substitution of mature forest specialists by disturbed forests opportunists (Costantini et al. 2016). This may explain why assemblage structure (NMDS1) changed over time both in the logged and in the unlogged forests and became more similar during the fifth year after logging. Among those sensitive species, we detected forest specialists found in the understory and on the ground level (e.g., Thamnomanes ardesiacus, Thamnomanes caesius, Epinecrophylla gutturalis, and Myrmotherula longipennis). The population of these species is usually reduced in disturbed environments (Aleixo 1999, Henriques et al. 2008). Other species (e.g., Terenotriccus erythrurus, Schiffornis turdina, Mionectes oleagineus, and Pheugopedius coraya) are usually found in disturbed forests and may benefit from environmental changes (Cohn-Haft et al. 1997, Borges 2007). These changes may result in differences in the assemblage structure in logged and unlogged forests.

The increasing similarity in assemblage structure between logged and unlogged areas suggests a decrease of environmental impacts in a relatively short time period (five years after logging). Thus, the results may indicate the positive effects of ecological succession on bird biodiversity by the substitution of species by those typically found in undisturbed forests (Matos et al. 2018). This may explain why in the fifth year after logging forest specialist species were captured in the logged area, and those were absent in previous years (e.g., Pithys albifrons, Gymnopithys rufigula, and Automolus ochrolaemus). These species forage on the ground and in the understory, and are susceptible to environmental disturbances (Cohn-Haft et al. 1997, Laurance et al. 2004, Stouffer 2007). However, low-impact logging areas may also function as sink in a metapopulational system, in such a way that species spill-over may be the cause of the increased similarity between logged and unlogged areas (Tscharntke et al. 2012). In this case, the return of species after disturbance may not necessarily indicate the recovery of the forest ecosystem and environmental quality.

Variation in assemblage structure over time was less intense in the unlogged area. This may be a result of the conservation of important ecological processes and factors that help maintaining wildlife communities at equilibrium (Berry et al. 2010, Edwards et al. 2014). Thus, the increase in similarity between logged and unlogged areas indicates that time after logging may be the most important factor for recovering wildlife communities in areas under SFM (Costa \& Magnusson 2003).

\section{Conclusions}

Our results suggest that the effects of low-impact logging altered bird assemblage structure and that the similarity between logged and unlogged areas gradually increased over a short period of time after harvesting. Species richness and the number of individuals captured were similar between logged and unlogged areas. The observed impacts were not intense and changes in the assemblage suggest an ongoing process of recovery, probably facilitated by the proximity of logged and unlogged areas and by the reduced impact of logging in the study area. Long-term effects of SFM on bird assemblages remain to be tested.

\section{Acknowledgements}

We would like to thank all the people who helped in the fieldwork. We thank the Coordenação de Aperfeiçoamento de Pes- soal de Nível Superior (CAPES) and the Conselho Nacional de Desenvolvimento Científico e Tecnológico (CNPq) for providing financial support to the postgraduation programs of the authors. This work was supported by the Fundação de Amparo à Pesquisa do Estado do Amazonas (FAPEAM) for granting a scientific initiation scholarship to JCRS and for supporting the work of RASC (FIXAM 062.01637/2018).

\section{References}

Aleixo A (1999). Effects of selective logging on a bird community in the Brazilian Atlantic Forest. The Condor 101: 537-548. - doi: 10.2307/1370183 Barlow J, Haugaasen T, Peres CA (2002). Effects of ground fires on understorey bird assemblages in Amazonian forests. Biological Conservation 105: 157-169. - doi: 10.1016/S0006-3207 (01)00177-X

Berry NJ, Phillips OL, Lewis SL, Hill JK, Edwards DP, Tawatao NB, Ahmad N, Magintan D, Khen CV, Maryati M, Ong RC, Hamer KC (2010). The high value of logged tropical forests: lessons from northern Borneo. Biodiversity and Conservation 19 (4): 985-997. - doi: 10.1007/s10531-0109779-z

Batisteli AF, Tanaka MO, Souza AL (2018). Bird functional traits respond to forest structure in riparian areas undergoing active restoration. Diversity 10 (3): 90. - doi: 10.3390/d10030090

Bicknell J, Peres CA (2010). Vertebrate population responses to reduced-impact logging in a neotropical forest. Forest Ecology and Management 259: 2267-2275. - doi: 10.1016/j.foreco.201 0.02 .027

Borah B, Quader S, Srinivasan U (2018). Responses of interspecific associations in mixedspecies bird flocks to selective logging. Journal of Applied Ecology 55: 1637-1646. - doi: 10.1111/ 1365-2664-13097

Borges SH (2007). Bird assemblages in secondary forests developing after slash-and-burn agriculture in the Brazilian Amazon. Journal of Tropical Ecology 23: 469-477. - doi: 10.1017/SO2 66467407004105

Chaves WA, Sieving KE, Fletcher-Jr RJ (2017). Avian responses to reduced-impact logging in the southwestern Brazilian Amazon. Forest Ecology and Management 384: 147-156. - doi: 10.1016/j.foreco.2016.10.042

Cleary DF, Boyle TJ, Setyawati T, Anggraeni CD, Loon EEV, Menken SB (2007). Bird species and traits associated with logged and unlogged forest in Borneo. Ecological Applications 17: 11841197. - doi: 10.1890/05-0878

Cohn-Haft M, Whittaker A, Stouffer PC (1997). A new look at the "species-poor" central Amazon: the avifauna north of Manaus, Brazil. Ornithological Monographs 48: 205-236. - doi: 10.2307/40157535

Costantini D, Edwards DP, Simons MJ (2016). Life after logging in tropical forests of Borneo: a meta-analysis. Biological Conservation 196: 182188. - doi: 10.1016/j.biocon.2016.02.020

Costa FRC, Magnusson WE (2003). Effects of selective logging on the diversity and abundance of flowering and fruiting understory plants in a Central Amazonian Forest. Biotropica 35: 103114. - doi: 10.1111/j.1744-7429.2003.tboo267.x Dauber E, Fredericksen TS, Penã-Claros M 
(2005). Sustainability of timber harvesting in Bolivian tropical forests. Forest Ecology and Management 214: 294-304. - doi: 10.1016/j.for ec0.2005.04.019

De Graaf NR, Poels RLH (1990). The CELOS management system: a polycyclic method for sustained timber production in South American rain forest. In: "Alternatives to Deforestation: Steps Towards Sustainable use of the Amazon Rain Forest" (Anderson AB ed). Columbia University Press, New York, USA, pp. 116-127. [online] URL: http://www.cabdirect.org/cabdirect/ abstract/19920662891

Edwards DP, Tobias JA, Sheil D, Meijaard E, Laurance WF (2014). Maintaining ecosystem function and services in logged tropical forests. Trends in Ecology and Evolution 29: 511-520. doi: 10.1016/j.tree.2014.07.003

Gatti RC, Castaldi S, Lindsell JA, Coomes DA, Marchetti M, Maesano M, Valentini R (2015). The impact of selective logging and clearcutting on forest structure, tree diversity and above-ground biomass of African tropical forests. Ecological Research 30: 119-132. - doi: 10.1007/s11284-014-1217-3

Guilherme E, Cintra R (2001). Effects of intensity and age of selective logging and tree girdling on an understorey bird community composition in central Amazônia, Brazil. Ecotrópica 7: 77-92.

Hansen MC, Potapov PV, Moore R, Hancher M, Turubanova SA, Tyukavina A, Thau D, Stehman SV, Goetz SJ, Loveland TR, Kommareddy A, Egorov A, Chini L, Justice CO, Townshend JR (2013). High-resolution global maps of $21^{\text {st }}$-century forest cover change. Science 342 (6160): 850-853. - doi: 10.1126/science. 1244693

Henriques LMP, Wunderle-Jr JM, Oren DC, Willig MR (2008). Efeitos da exploração madeireira de baixo impacto sobre uma comunidade de aves de sub-bosque na Floresta Nacional do Tapajós, Pará, Brasil [Effects of low impact selective logging on an understory bird community in the Tapajós National Forest, Pará, Brazil]. Acta Amazonica 38: 267-290. [in Portuguese] - doi: 10.1590/S0044-59672008000200010 Ibarra JT, Martin M, Cockle KL, Martin K (2017). Maintaining ecosystem resilience: functional responses of tree cavity nesters to logging in temperate forests of the Americas. Scientific Reports 7: 1-9. - doi: 10.1038/s41598-017-04733-2 Jamhuri J, Samantha LD, Tee SL, Kamarudin N, Ashton-Butt A, Zubaid A, Lechner AM, Azhar B (2018). Selective logging causes the decline of large-sized mammals including those in unlogged patches surrounded by logged and agricultural areas. Biological Conservation 227 (1): 40-47. - doi: 10.1016/j.biocon.2018.09.004

Jati AS, Samejima H, Fujiki S, Kurniawan Y, Aoyagi R, Kitayama K (2018). Effects of logging on wildlife communities in certified tropical rainforests in East Kalimantan, Indonesia. Forest Ecology and Management 427: 124-134. - doi: 10.1016/j.foreco.2018.05.054

Jonkers WBJ, Hendrison J (2011). The CELOS Management System: concept, treatments and costs. In: "Sustainable Management of Tropical Rainforests: the CELOS Management System" (Weeger MJA ed). Tropenbos International, Paramaribo, Suriname, pp. 29-73. [online] URL: http://library.wur.nl/WebQuery/wurpubs/fulltex $\mathrm{t} / 197128$

Laurance SGW, Stouffer PC, Laurance WF (2004). Effects of road clearings on movement patterns of understory rainforest birds in Central Amazonia. Conservation Biology 18: 1099-1109. doi: 10.1111/j.1523-1739.2004.00268.x

Lewis OT (2009). Biodiversity change and ecosystem function in tropical forests. Basic and Applied Ecology 10: 97-102. - doi: 10.1016/j.baae. 2008.08.010

Lindenmayer DB, Blanchard W, Blair D, Westgate MJ, Scheele BC (2019). Spatiotemporal effects of logging and fire on tall, wet temperate eucalypt forest birds. Ecological Applications 29 (8): 339. - doi: 10.1002/eap.v29.8

Matos VPVD, Matos TPVD, Cetra M, Valente RA (2018). Forest fragmentation and impacts on the bird community. Revista Árvore 42 (3): 19. doi: 10.1590/1806-90882018000300009

MacDicken KG, Sola P, Hall JE, Sabogal C, Tadoum $M$, Wasseige $C$ (2015). Global progress toward sustainable forest management. Forest Ecology and Management 352: 47-56. - doi: 10.1016/j.foreco.2015.02.005

Mestre LA, Cosset CC, Nienow SS, Krul R, Rechetelo J, Festti L, Edwards DP (2020). Impacts of selective logging on avian phylogenetic and functional diversity in the Amazon. Animal Conservation 23 (6): 725-740. - doi: 10.1111/acv.v23.6 Michel NL, Whelan CJ, Verutes GM (2020). Ecosystem services provided by Neotropical birds. The Condor 122: 1-21. - doi: 10.1093/condor/dua a022

Montejo-Kovacevich G, Hethcoat MG, Lim FK, Marsh CJ, Bonfantti D, Peres CA, Edwards DP (2018). Impacts of selective logging management on butterflies in the Amazon. Biological Conservation 225: 1-9. - doi: 10.1016/j.biocon.201 8.06.012

Oliveira AND, Amaral ILD, Ramos MBP, Nobre AD, Couto LB, Sahdo RM (2008). Composição e diversidade florístico-estrutural de um hectare de floresta densa de terra firme na Amazônia Central, Amazonas, Brasil [Composition and floristic-structural diversity of a hectare of Terra Firme Dense Forest in Central Amazonia, Amazonas, Brazil]. Acta amazônica 38: 627-641. [in Portuguese] - doi: 10.1590/S0044-5967200 8000400005
Putz FE, Sist P, Fredericksen T, Dykstra D (2008). Reduced-impact logging: challenges and opportunities. Forest Ecology and Management 256: 1427-1433. - doi: 10.1016/j.foreco.2008.03. 036

Shearman P, Bryan J, Laurance WF (2012). Are we approaching "peak timber" in the tropics? Biological Conservation 251: 17-21. - doi: 10.1016/ j.biocon.2011.10.036

Sist P, Ferreira FN (2007). Sustainability of reduced-impact logging in the eastern Amazon. Forest Ecology and Management 243: 199-209. - doi: 10.1016/j.foreco.2007.02.014

Stouffer PC (2007). Density, territory size, and long-term spatial dynamics of a guild of terrestrial insectivorous birds near Manaus, Brazil. The Auk 124: 292-306. - doi: 10.1093/auk/124.1. 291

Thinh VT, Doherty-Jr PF, Huyvaert KP (2012). Effects of different logging schemes on bird communities in tropical forests: a simulation study. Ecological Modelling 243: 95-100. - doi: 10.1016/j. ecolmodel.2012.06.005

Tscharntke T, Tylianakis JM, Rand TA, Didham RK, Fahrig L, Batary P, Bengtsson J, Clough Y, Crist TO, Dormann CF, Ewers RM, Fründ J, Holt RD, Holzschuh A, Klein AM, Kleijn D, Kremen C, Landis DA, Laurance W, Lindenmayer D, Scherber C, Sodhi N, Dewenter-Steffan I, Thies C, Van Der Putten WH, Westphal C (2012). Landscape moderation of biodiversity patterns and processes - eight hypotheses. Biological Reviews 87 (3): 661-685. - doi: 10.1111/j.1469-185X.2011. 00216.x

Wellhöfer S (2002). Environmentally sound forest harvesting in Brazil: assessment of regeneration and environmental impacts four years af ter harvesting. Food and Agriculture Organization of the United Nations, Rome, Italy. [online] URL: http://www.fao.org/3/Y4345E/Y4345Eoo. htm

Whelan CJ, Wenny DG, Marquis RJ (2008). Ecosystem services provided by birds. Annals of the New York Academy of Sciences 1134: 2560. - doi: 10.1196/annals.1439.003

Wunderle Jr JM, Henriques LMP, Willig MR (2006). Short-term responses of birds to forest gaps and understory: an assessment of reduced-impact logging in a lowland Amazon Forest. Biotropica 38: 235-255. - doi: 10.1111/j.17447429.2006.00138.x

\section{Supplementary Material}

Tab. S1 - List of bird species and families, with the number of individuals captured per year in the logged and in the unlogged areas.

Link: Soares_3435@supplo01.pdf 